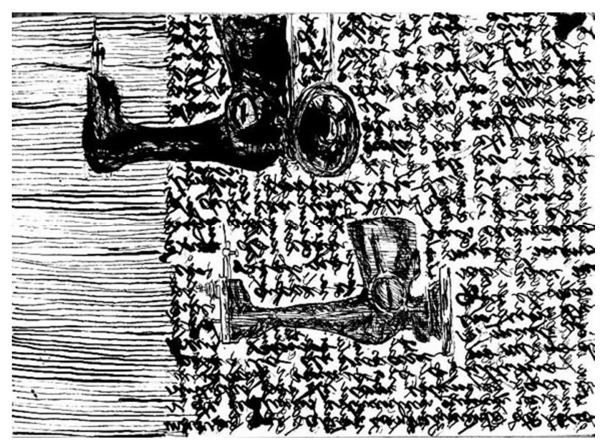

Ilustração Milton Lira

\title{
A telinha e o texto
}

\section{João Baptista Santiago Sobrinho}

João Baptista Santiago Sobrinho é escritor, professor de literatura, Mestre em Teoria da Literatura pela UFMG e doutorando em Literatura Brasileira pela mesma Universidade.

Seu fedelho!

(versão brasileira: Herbert Richards)

Como leitor do mundo, até os dez anos de idade, fui bom. Rua riachos rios. O céu. Histórias. Cerca de bambu. Manga, laranja, abacate, caju. Do rádio ... "Juvêncio o justiceiro do sertão e... Jerônimo o herói do sertão". Só me lembro dos prefixos. Vinha da casa da Julinha. Ela tinha hanseníase. Nossa mãe proibiu. Julinha sarou, casou e foi feliz. Casou com o Cigano. Todas as moças queriam com ele casar. A televisão não existia em casa. Um dia ela chegou. A antena bonita, como a espinha sem o peixe. Dia de aprumá-la exigiu união. Um tubo de ferro, ruína de um brinquedo giratório, de quatro acentos, que tínhamos no quintal, foi o mastro. Na base amparava-o um rolimã ajustado num pedaço tronco de cabiúna ou peroba. De modo que girava fácil na busca pelos canais. Em tudo, meu pai, antes de comprar, tentava fazer. Não faltaram foguetes. Meu pai levava a sério até batismo de boneca. Antes. Vi a primeira Copa, a de setenta, porque o aparelho que havia em nossa rua veio parar sob duas cadeiras, em frente à casa do, não sei, acho que do Sô-Loíde ou professor Montovani. Assim, assistimos o Tri. Nessa hora aquela moça de São Paulo, ainda não sendo noiva, pra-frente, sentava-se no colo do namorado. Tão boa era a indecência dela. As pernas sozinhas, pêlos que o sol da tarde... O vestido curtinho de alegria. Logo meu pai comprou um aparelho. A antena foi a maior de todas. Cada pedacinho uma zarabatana. A televisão foi despegando. E colocamos na 
tela papel celofane de três cores, de modo que ela ficou colorida. Foi assim que o Hermes passou a freqüentar minha casa. Gostava da novela. Hermes tinha um chulé olímpico, mas dava gosto, pagava a pena, ele tinha salvo-conduto: a enorme cicatriz. Nem Ulisses foi tão épico. Não sempre, vez em quando, mostrava-nos. Nooossa! Do gogó até o umbigo. "Quando eu crescer quero uma". E ele fazia assim com a mão, mostrando-nos o coração pra fora. Tanto jeito pra contar faz o sangue escorrer. Depois arregaçava o peito, imitando as garras, as costelas, e enfiava aquilo pra dentro. Porque ele não era bobo e não ia dormir com as pessoas enfiando nele a mão. Isso foi em 1971. Ah! Era... uma vez.

Antes eu vi, vi o cinema. Meu pai tinha cadeira cativa no cinema de seu Laerte, que de profissão era farmacêutico, médico, xamã, bilheteiro, lanterninha. De verdade, acho, era farmacêutico-prático. A cidade tinha um hospital. De primeira linha. Mas os médicos nunca vieram. Enferrujou.

A vida era muito simples. Escola, brinquedos, de segunda a sexta. Sábados e domingos, era o cinema. Para ir, eu engraxava sapatos. Cinco pares e eu tinha um bilhete de entrada. Se sobrava dinheiro, comprava figurinha pra jogar bafinho, bolinhas de gude. Depois o cinema mudou de dono, Sô-Laerte foi embora - todos fomos - não mais era outra vez a mesma coisa, como o mesmo céu não se repete. Dos filmes que me lembro: Perseu, Massiste no Inferno, Hércules e os indefectíveis bang-bangs com Giulliano Gema, Franco Nero, John Wayne. Só mais tarde eu conheci John Ford, John Houston, Cantinflas, Roy Rogers, Oscarito, Carlitos, Bela Lugosi, Boris Carloff, Enio Morricone, Cristhofer Lee, José Ferrer, Errol Flynn, Randolf Scott, Rodolfo Valentino, Raquel Welch, Elizbeth Taylor, Sofia Loren, Monica Vitti, Lauren Bacall, Florinda Bolkan, Vitório de Cica, Sérgio Leone, Leolo, este último, enfio aqui, mas foi muito mais tarde. Marcaram-me profundamente os épicos, dizia-me que o certo é lutar pelos mais fracos e que a verdade vencia. Não faltaram os seriados de Rock Lane, Zorro e Tonto. Nunca assisti um completo. Daquela vez ganhei uns revólveres da Estrela, dois polícias invocaram, acharam de tomar-me, engambelados pela qualidade. Meu pai gostava de armas, eu, de fantasia.

Uma pornochanchada me deixou em maus-apuros, a película chamava-se Aconteceu no maracanã. Acho, ela foi meu primeiro porquinho da índia. Pois eu ainda tinha horror às moças de verdade. Beijo? Eco!!! Mas aquele cartaz, aquela mulher... Perguntei ao seu Laerte se meu pai estava no cinema, ele disse que não. "Posso entrar?" Ele disse: "Espere". Voltou sorrindo. Entrei. Esperei um lance claro na tela. Olhei para a cadeira de meu pai. Ninguém lá. Sentei-me ao meio do cine-teatro - como pude esquecer-lhe o nome? - Não em meu lugar, na primeira cadeira, na fila à esquerda. Quase dentro da tela. Assisti um pouco do filme, quando uma mão cutucou-me o ombro e uma voz 
disse: "Vá para casa, depois eu te dou um doce". Santo Deus! Além do pecado mortal - um filme todo proibido - o couro ia cantar. Fui para casa. Escondi-me no balaião de roupas sujas. Espécie de caldeira. Os suores da família. Que calor! Adormeci. Acordei em minha cama. Meu pai havia me levado para lá. Talvez tenha me dito coisas, dessas que tentamos lembrar, mas a infância é galope esquivo aos tempos em que toda realidade é fabricável. O pai era austero. Mas delicadamente, como num filme, o terror elidiu-se, com num plano longo - depois da batalha - o herói vai rumo ao horizonte. Fui confessar, os pecados de praxe, mais um: Desobedeci minha mãe, meu pai, xinguei meus irmãos, roubei laranja, fui ao cinema - Deus te abençôe... e ir ao cinema não é pecado sô! - Muitos anos depois, Januário - meu irmão mais velho - disse que todas as sessões de cinema - aquelas de quando não havia dinheiro e o sô-Laerte deixava-nos entrar - eram pagas por meu pai. Mas não assisti Sansão e Dalila com Hedi Lamar e Victor Mature. O pai não deixou. Estávamos indo ao cinema. Eu e os dois irmãos mais velhos, José e Januário. Quase na esquina ouvimos o assobio. Dois toques agudos, sendo que o último se esticava, subia e fechava de brusco. Voltamos correndo. O pai disse que não íamos ao cinema naquele dia. Não me lembro do motivo. Podia não haver. Mas lembro que a família inteira foi ao cinema no dia seguinte. Não queríamos ir e, emburrados, assistimos Perseu. Adorei o filme. Perseu lutou com a Górgona e com árvores carnívoras. Sansão e Dalila o máximo em cinemascope. Tecnicolor? Nossa!!! Não o vimos, o filme, na jardineira, de manhãzinha, foi-se.

Meu pai trazia pra gente revistas em quadrinhos. Muitas. Flash Gordon, Tarzan, Mandrake, Tex, Capitão Marvel, Batman, O Homem de ferro, O Homem-aranha, Thor, Capitão-américa, Superman...

Havia, vez em quando, o circo. Circo Teatro Caxambu e o Palhaço Pardal, que era também o galã das impagáveis encenações de Coração Materno. Como chorávamos vendo o filho arrancar o coração da mãe e levá-lo para a amante e depois o arrependimento tardio do filho. Pensava em minha mãe - a voz de Vicente Celestino no alto falante ela tinha doença de Chagas. Mudava a história. Como bom filho eu terminava com a moça. Eco!! E pedia a Jesus um coração novo, mas igual de amor, pra minha mãe. Ninguém no mundo chorou mais do que eu ao assistir Cinema paradiso, nunca vi São João Batista do Glória tão bem retratada. Mas depois mudamos de cidade. Fomos para Rio Pomba. O cinema era maior, de dois andares. No de cima, geralmente, ficavam os namorados e embaixo a molecada. Bom era peidar no cinema. Fazíamos espécie de guerrilha flatulenta. Antes comíamos cebola, ovo, batata doce, bebíamos vitamina de abacate, café com leite. Um grande arsenal. Cada um com sua dieta. Escolhíamos os filmes românticos. Sentávamos em frente aos casais e namorados e largávamos - metano. Sempre um de cada vez. Batíamos na barriga, para deslocar - gás, que deveria sair sem barulho. Mas peido é coisa desobediente, dedurava-se, e o cinema polvorava palavrões e gargalhadas. Não 
peguei o tempo da dona Climeni que descia a sombrinha na cabeça de quem sentasse em sua cadeira. Mas foi ali que assisti, pela primeira vez, duas sessões, pagando apenas um ingresso. Que realização, quatro horas dentro do cinema: Maciste no inferno, fomos eu e minha irmã, a Justininha.

Fui uma única vez ao cinema com meu pai, assistimos Tubarão do Steven Spilberg. Meu pai ficou... Ele se chamava Santiago. Adorou quando viu o tamanho do tubarão. Achou tudo perfeito. Um pouco triste, mas embevecido com a morte do tubarão. Parecia... como definir um pai, ao seu lado, assistindo cinema? Fomos para casa conversando sobre Ernest Hemingway. O velho e o mar, que ele havia me indicado, por essa época ele só lia livrinhos de bolso.

Ah! A televisão. Vi tanta coisa... não me lembro. Exceto da moça, cujas pernas. Ah! Mas logo chegaram os livros. Razão pela qual fiquei doido. Totalmente diferente. Fora. Taciturno. Ler exige rugas, viagens saturnais. Sabemos que estamos doidos, quando nos apontam com o dedo ou dizem: "Então é você que é o fulano, filho do beltrano, mais a sicrana?" Guerra e Paz causou-me terrível arrebatamento. Pra conter-me contavam-me a história de um homem que acabou de "comê garrolê e morreu." Será? "garrolê era algum tipo de rocambole envenenado?" Mas nada me afastava dos livros. O mundo pela textura é o único possível. Quem agüenta a vida? Melhor Tempos dificeis de Charles Dickens ou Caninos brancos de Jack London. Melhor Confesso que vivi de Pablo Neruda ou Alguma poesia de Drummond. Melhor Zorba, o grego de Nikos Kazantzakis ou Grande Sertão: veredas de João Guimarães Rosa.

O homem foi à lua. Porém não se conseguiu convencer ao Zé-do-Padre, nem disso, nem de que existia elefante.

Os livros migraram-me como o pássaro não se separa da paisagem ou o coração da pele. Então, "ante o que murchou", perfiz inventada memória. A vida é adornável, tessitura. 